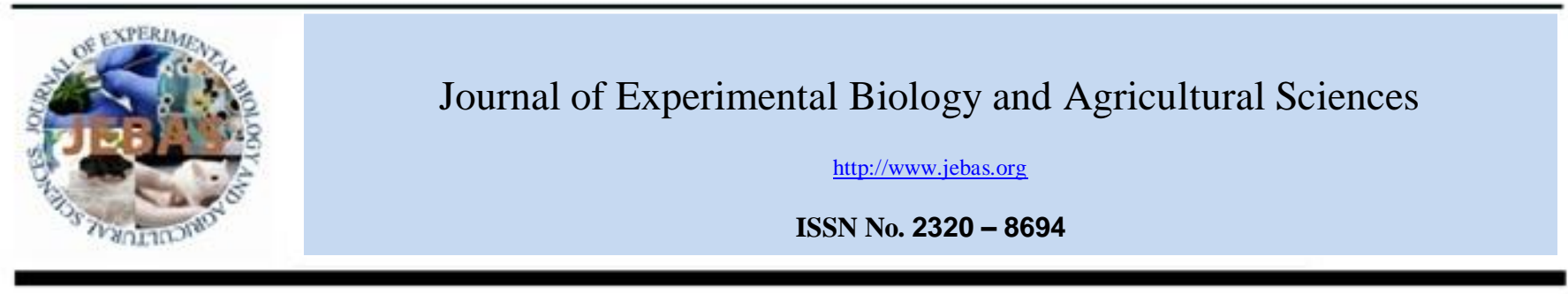

\title{
MONITORING OF AFLATOXIN CONTAMINATION AT MARKET FOOD CHAIN IN EAST JAVA
}

\section{Agustina A. Rahmianna* and Eriyanto Yusnawan}

Indonesia Legumes and Tuber crops Research Institute (ILETRI), Jalan Raya Kendalpayak Km 8 Malang, PO Box 66 Malang 65101 East Java, Indonesia

Received - April 20, 2015; Revision - May 08, 2015; Accepted - July 31, 2015

Available Online - August 20, 2015

DOI: http://dx.doi.org/10.18006/2015.3(4).346.352

\begin{abstract}
KEYWORDS
Peanut

Aflatoxin contamination

Aspergillus flavus

Seed moisture content

Damage seed

ABSTRACT

Peanut is a cheapest source of protein especially for developing countries communities and mostly it obtained from traditional markets. Earlier studies showed that aflatoxin incidence was relatively less at the farmer/trader levels while it is significantly higher at retail levels especially in traditional markets. Present study was conducted to understand the factors leading to the post-harvest building up of aflatoxin in peanuts sold in traditional market and in supermarket. This study was carried out at Pasuruan regency, East Java Province, Indonesia from March 2005 to June 2006. During study period peanut grains were collected from wholesalers, retailers and supermarkets at three months interval. In each sampling point, $2 \mathrm{~kg}$ of grains was obtained and then was divided into eight parts for the analysis of parameters namely seed moisture content, physical quality, Aspergillus flavus infection and aflatoxin $\mathrm{B}_{1}$ contamination. The results showed that seed water contents at wholesalers, collectors, and retailers in traditional wet markets were almost lower than $10 \%$. They were thus 'safe' from aflatoxin $\mathrm{B}_{1}$ contamination as seed moisture contents were below the aflatoxin risk zone. Time of sampling did not affect the level of aflatoxin $B_{1}$ contamination. Under controlled condition generated from air-tight container, the influence of seed moisture content and A. flavus infection on aflatoxin production was significant.
\end{abstract}

* Corresponding author

E-mail: aa.rahmianna@litbang.pertanian.go.id (Agustina A. Rahmianna)

Peer review under responsibility of Journal of Experimental Biology and Agricultural Sciences.

Production and Hosting by Horizon Publisher (www.myvision.webs.com/horizon.html)

All rights reserved.
All the article published by Journal of Experimental Biology and Agricultural Sciences is licensed under a Creative Commons Attribution-NonCommercial 4.0 International License Based on a work at www.jebas.org.

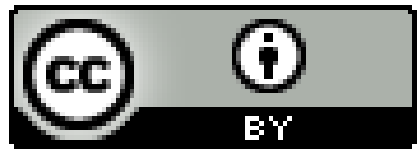




\section{Introduction}

Community awareness related to the risk of aflatoxin contamination is still low especially for people who have limited access to education and information. Aflatoxin is a carcinogen, immune suppressing and anti-nutritional natural contaminant of peanuts and hence is a major food and feed quality problem worldwide (Wotton \& Strange, 1985; Paramawati et al., 2006). This toxin produced by soil-borne fungi Aspergillus flavus, A. paraciticus and A. nomius (Pitt \& Hocking, 1997) in peanut kernels. These fungi can colonized and infect peanut even when the crops are on farm, which represent that aflatoxin production in peanut seeds occur at both pre and post harvesting stages. Pre-harvested aflatoxin contamination occurs when peanut suffered from drought stress especially during late generative growth phase (seed maturation). Meanwhile post-harvest contamination usually proceeds when the seeds are in warm and humid conditions either during storage or transportation (Yameogo \& Kassamba, 1999).

Extensive surveys on aflatoxin contamination at various levels of the Indonesian peanut supply chain have found that aflatoxin incidence was very minor at the farmer and collector level where peanut is produced and sun-dried, respectively (Dharmaputra et al 2003; Dharmaputra et al 2007; Rahmianna et al 2007a). The toxin contamination increased as peanut seeds went through the next level of supply chain i.e. the marketing sectors especially at retail level in traditional market; here the contamination was generally found to be the highest. This indicates that aflatoxin contaminated peanuts entered in the marketing chain, post-harvest contamination of aflatoxin build up due to poor storage conditions (Dharmaputra et al., 2003; Dharmaputra et al., 2004; Rahmianna et al., 2007; Ndung'u 2013).

Early results of various studies confirmed that A. flavus is highly prevalent in kernel samples stored at wholesaler and wet markets with temperature $\left(25\right.$ to $35^{\circ} \mathrm{C}$ ) and relative humidity (up to $60 \%$ ) conditions being highly conducive for aflatoxin production (Dharmaputra et al., 2003, Dharmaputra et al., 2004; Rahmianna et al., 2007). Though Peanut is a cheapest and important source of protein for population of developing countries, and the current study is proposed to enhance our understanding of factors leading to the post-harvest build up of aflatoxin in peanuts during storage in three different selling points (i.e. wholesaler, traditional 'wet' market and supermarket) in Indonesia. The objective of this research was to understand the incidence of aflatoxin contamination at three market types during wet and dry seasons of study period.

\section{Materials \& Methods}

A monitoring study was conducted by collecting peanut kernels from the available points of market food chain in one of the central production areas at East Java Province, i.e. Pasuruan regency. In this regency, peanut is an important secondary food crop and the grains are popularly consumed either as food (peanut sauce, peanut cracker, etc) or in various snacks. The monitoring study was conducted for 16 months (from March 2005 to June 2006) with sampling scheduled in every three months during the storage period (a total of 6 samplings: March, June, September, and December in year 2005, while in year 2006 was March and June). These six samplings covered both dry and wet seasons, where from April to October was dry season and November to March was wet season. Peanut samples were collected from one wholesaler (who distributes peanuts to traditional/wet market), three shops/retailers in traditional market, and one supermarket.

At retailer, wholesaler and supermarket levels, three samples were obtained in every sampling time as replication. An analysis of variance was performed using a randomized block design with two factors and three replications. Time of sampling (six sampling times) was factor 1 and market type (three market types) as factor 2 .

The size of each sample was two $\mathrm{kg}$ of seeds. The air dried seed were divided in eight parts by using a seed divider to obtain working samples for analysing moisture content, physical quality, percent of kernel infected by A. flavus and aflatoxin $B_{1}$ content (Dharmaputra et al., 2004). The procedure for obtaining the working samples from the main peanut samples described in the figure 1 .

The moisture content of peanut kernels was measured by gravimetric method. Physical quality of seed kernels was quantified by manually segregating seed sample into three seed qualities i.e. sound mature kernel (SMK), shriveled and damaged kernels (only data on damaged kernels provided in this paper). The damaged kernels included those cracked, broken, discolored, and damaged by insects or fungi. The percentage of seeds infected by A. flavus was determined by plating 100 seeds per sample onto the Aspergillus flavus and parasiticus agar (AFPA) media in 10 petri dishes (as replications) or 10 seeds per each petri dish. The seeds were incubated for 3 days.

The A. flavus infection was easily determined by the presence of fungal colonies as shown by dark yellow or orange colour at the bottom of the media. Aflatoxin $\mathrm{B}_{1}$ content in the seeds was determined using Elisa method (Lee \& Kennedy 2002). Briefly, samples for aflatoxin $\mathrm{B}_{1}$ were extracted with methanol. Supernatant was separated from the pellet. A competitive ELISA was performed to measure aflatoxin $B_{1}$ in the supertanant. The absorbance values were determined using spectrophotometer and plotted against a standard curve of aflatoxin $\mathrm{B}_{1}$. The aflatoxin $\mathrm{B}_{1}$ contents of the samples were expressed in part per billion (ppb). 


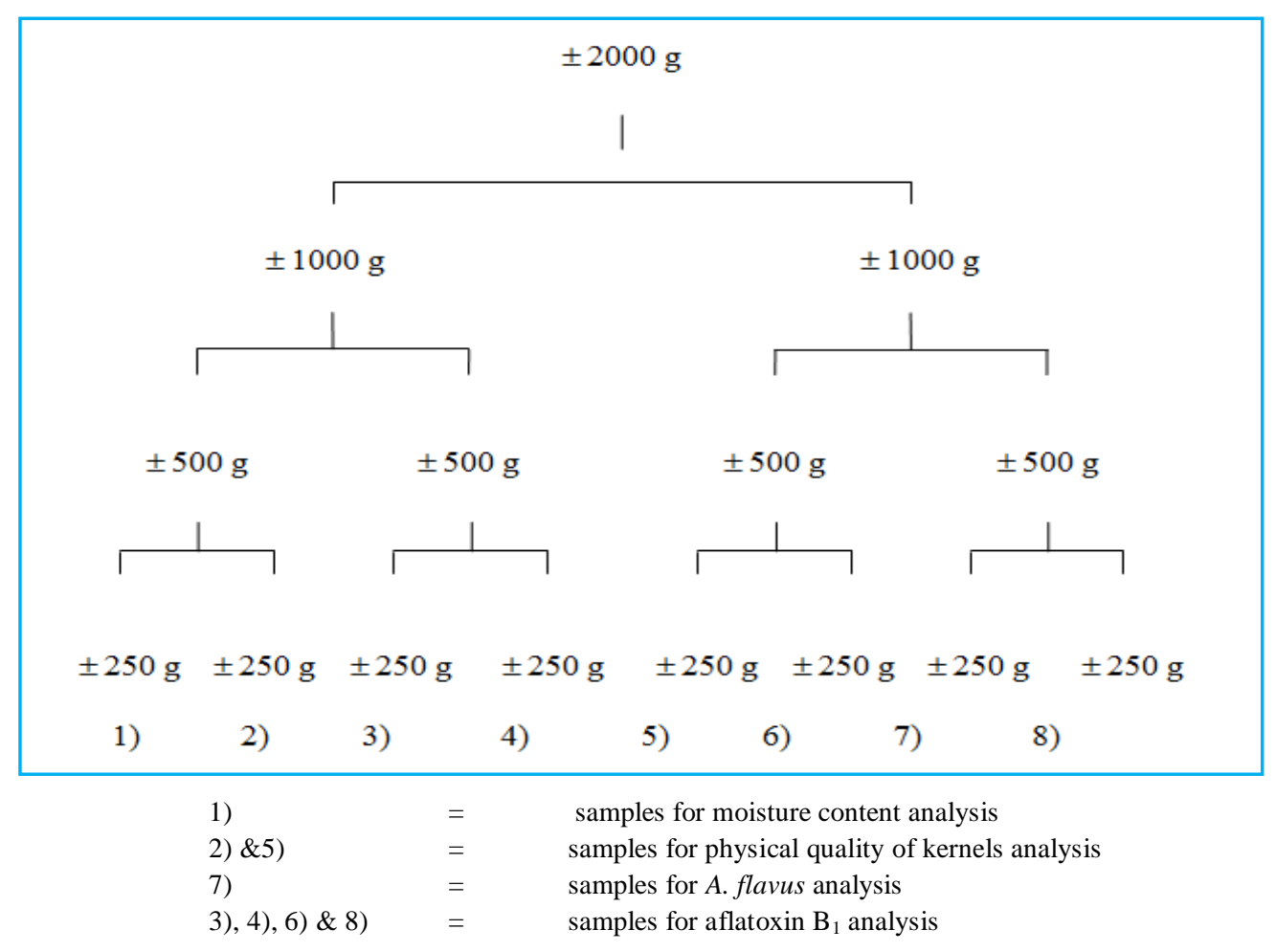

Figure 1 The procedure for obtaining the working samples from the main peanut samples. [Source: Dharmaputra et al. (2004) ]

\section{Results}

\subsection{Seed Moisture Contents}

Entire samples obtained from three market types during the various study periods, the seed water moisture contents were found to be $<10 \%$, except from one sample that revealed kernels with moisture content $>10 \%$. This high seed moisture content was obtained from retailer at traditional market in March 2006. Possible reason for this could be the usage of opened-wooden box for the storage of seeds in the shops for at least one week at ambient temperatures. The seeds obtained from supermarket, however, had lowest moisture content throughout the sampling times because peanut seeds were properly packed in air-tight packaging and stored under airconditioned environment. Samples obtained from wholesalers consistently contained 8-9\% moisture, as the seeds stayed for very short period with maximum 7 days in this point, and during storage, the seeds were packed in the gunny bag with minimum contact to the surrounding air (Table 1).

Table 1 Seed moisture contents of peanuts collected from three different market types in Pasuruan Regency from March 2005 to June 2006.

\begin{tabular}{|lccc|}
\multicolumn{1}{r}{ Sampling times } & \multicolumn{1}{c|}{ Market types } & Supermarket \\
\hline March 2005 & Traditional market & Wholesaler & $6.3 \mathrm{~cd}$ \\
\hline June 2005 & $8.9 \mathrm{~b}$ & $8.6 \mathrm{~b}$ & $7.5 \mathrm{bcd}$ \\
\hline September 2005 & $6.4 \mathrm{~cd}$ & $8.2 \mathrm{bc}$ & $6.3 \mathrm{~cd}$ \\
\hline Januari 2006 & $7.9 \mathrm{bc}$ & $7.9 \mathrm{bc}$ & $6.3 \mathrm{~cd}$ \\
\hline March 2006 & $8.0 \mathrm{bc}$ & $7.7 \mathrm{bcd}$ & $7.2 \mathrm{bcd}$ \\
\hline June 2006 & $12.1 \mathrm{a}$ & $8.3 \mathrm{bc}$ & $6.2 \mathrm{~cd}$ \\
\hline
\end{tabular}

Numbers followed by the same letter(s) indicated not significantly different based on DMRT 5\% 
Table 2 Percent of damaged seeds of peanuts collected from three different market types in Pasuruan Regency from March 2005 to June 2006.

\begin{tabular}{|lccc|}
\multicolumn{1}{c}{ Sampling times } & \multicolumn{2}{c|}{ Market types } & Supermarket \\
\hline March 2005 & $29.6 \mathrm{ij}$ & Wholesaler & 39.9 efgh \\
\hline June 2005 & $50.0 \mathrm{bcde}$ & $55.6 \mathrm{~b}$ & $52.1 \mathrm{bc}$ \\
\hline September 2005 & $35.0 \mathrm{hi}$ & $24.6 \mathrm{j}$ & 49.4 bcdef \\
\hline December 2005 & $50.5 \mathrm{bcd}$ & 45.4 bcdefg & 65.9 a \\
\hline March 2006 & 46.3 bcdef & $46.3 \mathrm{bcdef}$ & 40.2 defgh \\
\hline June 2006 & 42.5 cdefgh & 35.6 ghi & 39.5 \\
\hline
\end{tabular}

Numbers followed by the same letter(s) indicated not significantly different based on DMRT 5\%

Table 3 Percent of seeds infected by Aspergillus flavus on peanuts collected from three different market types in Pasuruan Regency from March 2005 to June 2006.

\begin{tabular}{|lccc|}
\multicolumn{1}{c}{ Sampling times } & \multicolumn{2}{c|}{ Market types } & Supermarket \\
\hline March 2005 & $11.6 \mathrm{~g}$ & Wholesaler & $42.3 \mathrm{bcde}$ \\
\hline June 2005 & $59.5 \mathrm{bc}$ & $34.6 \mathrm{defg}$ & $94.6 \mathrm{a}$ \\
\hline September 2005 & $34.3 \mathrm{defg}$ & $33.8 \mathrm{defg}$ & $16.0 \mathrm{fg}$ \\
\hline Januari 2006 & $25.6 \mathrm{efg}$ & $30.0 \mathrm{defg}$ & $21.0 \mathrm{efg}$ \\
\hline March 2006 & $52.5 \mathrm{bcd}$ & $40.2 \mathrm{cde}$ & $36.5 \mathrm{def}$ \\
\hline June 2006 & $23.3 \mathrm{efg}$ & $63.2 \mathrm{~b}$ & $30.5 \mathrm{defg}$ \\
\hline
\end{tabular}

Numbers followed by the same letter(s) indicated not significantly different based on DMRT 5\%

\subsection{Physical quality}

Despite three categories of physical quality observed, only data of damaged seeds are presented in this paper since the damage seeds had more risk in or were more prone to A. flavus infection and aflatoxin $\mathrm{B}_{1}$ contamination based on our previous studies (Rahmianna et al 2007a,. Rahmianna et al 2007b). In general, the data indicated that percent of damage seeds were high ranging from $24.8 \%$ to $65.9 \%$ in three market points. Percent of damaged seeds at wholesaler was generally lower than those at retailer level from six sampling times, except for samples taken in March and September 2005 (Table 2).

Peanuts sold in the supermarket did not always have good quality seeds in terms of seed coat color, intactness and healthiness as pointed out by the sample obtained in June, September, and ultimately December (Table 2).

\subsection{Infection of A. flavus}

Peanut seeds from all market chains were infected by A. flavus at various levels, ranging from $11 \%$ to almost totally infected (Table 3). The percentage of infection range was very wide, especially for peanut from retailers in traditional market. Among sampling time, samples taken in September 2005 had low infection rate in all three market points.

3.4 Aflatoxin $\mathrm{B}_{1}$ contamination
The aflatoxin $\mathrm{B}_{1}\left(\mathrm{AFB}_{1}\right)$ contamination in most samples from all three market types in Pasuruan regency was $>10 \mathrm{ppb}$. In addition, some samples had unacceptable levels of aflatoxin since of its extremely high contamination (>3000 ppb) (Table 4). In general, the number of samples with aflatoxin content $>10 \mathrm{ppb}$ from retailers was higher compared to those obtained from wholesale and supermarket, except samples taken in March and June 2006 (Table 5).

The higher contamination incidence at retailer level was due to the longer period of storage under conditions that favorable for the fungus to produce this secondary metabolite before the seeds were processed for food.

\section{Discussion and Conclusions}

Any peanut kernel with moisture content $\geq 10 \%$ is stayed in aflatoxin risk zone as the critical moisture for aflatoxin production is in the range of $10-30 \%$ (Crop Link, 2000). Having low aflatoxin contamination, the kernels should contain $7-8 \%$ moisture and therefore the dry seeds had to be kept under air-tight $0.05 \mathrm{~mm}$ poly propylene bag. This condition was experienced by peanuts in wholesaler, where they were closely packed. Dried condition of seeds together with air-tight packed resulted in safe kernels with low aflatoxin contamination even up to six months storage (Dharmaputra, 2002; Ginting, 2006). 
Table 4 Aflatoxin $B_{1}$ content of peanuts collected from three different market types in Pasuruan regency from March 2005 to June 2006.

\begin{tabular}{|l|c|c|c|c|c|c|}
\hline \multicolumn{1}{|c}{ Market type } & \multicolumn{2}{c}{ Aflatoxin B $_{1}$ content (ppb) of peanuts samples } \\
\cline { 2 - 8 } & March 2005 & June 2005 & Sept 2005 & Dec 2005 & March 2006 & June 2006 \\
\hline Whole-sale & $6.4-10.7$ & $8.3-418.8$ & $6.7-137.5$ & $3.5-8.7$ & $5.6-453.4$ & $4.8-3583$ \\
\hline Super-market & 6.5 & 11.5 & 9.1 & 7.7 & 6.3 & 265.8 \\
\hline Retailer in traditional market & $1.7-18.1$ & $8.1-3074.9$ & $5.6-478.3$ & $3.8-90.9$ & $4.8-290.8$ & $4.4-187.7$ \\
\hline
\end{tabular}

* one sample only

Table 5 Percentage of seeds with aflatoxin $\mathrm{B}_{1}$ content lower and higher than $10 \mathrm{ppb}$ of peanuts collected from three different market types in Pasuruan regency from March 2005 to June 2006.

\begin{tabular}{|c|c|c|c|c|c|c|c|c|c|c|c|c|}
\hline \multirow[t]{3}{*}{ Market type } & \multicolumn{2}{|c|}{ March 2005} & \multicolumn{2}{|c|}{ June 2005} & \multicolumn{2}{|c|}{ Sept 2005} & \multicolumn{2}{|c|}{ Dec 2005} & \multicolumn{2}{|c|}{ March 2006} & \multicolumn{2}{|c|}{ June 2006} \\
\hline & $\leq 10$ & $>10$ & $\leq 10$ & $>10$ & $\leq 10$ & $>10$ & $\leq 10$ & $>10$ & $\leq 10$ & $>10$ & $\leq 10$ & $>10$ \\
\hline & $\mathrm{ppb}$ & $\mathrm{ppb}$ & $\mathrm{ppb}$ & $\mathrm{ppb}$ & $\mathrm{ppb}$ & ppb & $\mathrm{ppb}$ & $\mathrm{ppb}$ & ppb & $\mathrm{ppb}$ & $\mathrm{ppb}$ & $\mathrm{ppb}$ \\
\hline Whole-sale & 72.7 & 27.3 & 70.0 & 30.0 & 76.9 & 23.1 & 100 & 0 & 20.0 & 80.0 & 60.0 & 40.0 \\
\hline Super-market ${ }^{*}$ & 100 & 0 & 100 & 0 & 100 & 0 & 100 & 0 & 100 & 0 & 0 & 100 \\
\hline Traditional market & 81.3 & 18.7 & 38.1 & 61.9 & 64.7 & 35.3 & 89.0 & 11.0 & 89.0 & 11.0 & 85.7 & 14.3 \\
\hline
\end{tabular}

one sample only

High number of damaged seeds in traditional market was in accordance to the results obtained from six retailers at traditional markets in Banjarnegara region of Central Java, where there was an average of $45 \%$ damaged seeds with the range from 5 to $73.5 \%$ (Rahmianna et al., 2007a). The storage system practiced by retailers in the traditional market at Pasuruan (i.e. storing the grains in opened containers during the trading hours under ambient temperature) favored high incidence of damage seeds. Ginting (2006) concluded that when seeds were stored in opened containers under ambient temperature for 4 months generated huge damaged seeds by $80.9 \%$ compared to those kept in the $0.05 \mathrm{~mm}$ and 0.08 poly propylene bags with only 1.3 and $1.9 \%$ of damaged seeds, respectively. Seeds that were exposed to environment with free air rich in oxygen in the traditional market was stimulate the activity of microorganism both fungi and pest. Also, improper post harvest handling such as shelling (both manually and machinery) contributed to testa and/or cotyledons damage. This physical damage did not only found in peanut seeds obtained from in retailer level but that also found in wholesale level.

High A. Flavus infected seeds obtained from traditional market were also found in peanut seeds collected from traditional markets at Banjarnegara (Rahmianna et al., 2007), Pati (Dharmaputra et al., 2003), and Wonogiri regencies (Dharmaputra et al., 2004). In this monitoring study, high incidence of A. flavus infection in peanut obtained from supermarket was surprisingly. Since A. flavus is a soil borne fungus, the spores of A. flavus infected the pods during preharvest. The physical condition of pods and the intactness of testa plays an important role in entering the spores into the seeds and the development of hyphae onto the seeds, respectively (Mehan et al., 1983, Cole et al., 1985; Van Eden et al., 1994). Generally the fungal infection was getting serious when the seeds stayed in the marketing chains with poor storage condition as pointed out by high number of seeds infected by A. flavus. In contrast, the number of seeds infected by $A$. flavus was very low (4.8-5.6\% in average) at harvesting time in the farmer's field at Banjarnegara: (Rahmianna et al., 2007). According to Lubulwa \& Davis (1994) aflatoxin content of $1000 \mathrm{ppb}$ resulted in acute liver damage to human, livestock and poultry. High contamination at retailer level also happened in Cote-d'Ivoire of Africa (Pollet et al., 1992) as aflatoxin contamination built up during storage and transportation (Yameogo \& Kassamba, 1999).

Based on the data obtained in all market points during six times of sampling undertaken both in dry and wet seasons, aflatoxin contamination was directly governed mostly by seed moisture content rather than by the number of seeds infected by $A$. flavus and physical quality.(i.e. damaged seeds) as pointed out by correlation coefficient values of $0.517,0.384$ and 0.194 respectively.

Theoretically, aflatoxin production was governed by the level of A. flavus infection. Seed damage, among others, as a result of A. flavus infection, also played a significant role in aflatoxin production. The production of this secondary metabolite was also influenced by seed moisture content. All these theories were found significant in peanut seeds obtained from supermarket. These phenomena did not find in peanut seeds obtained from retailers and wholesalers. Air-tight container absolutely prevents the seeds from the interference of surrounding environment and air-conditioned storage room warrants the stable air temperature and relative humidity. Rahmianna et al. (2007) revealed the positive correlation between seed moisture content, which was from 4.2 to $17.6 \%$, in line with the moisture content which risky to aflatoxin contamination by $10-30 \%$ (Crop Link, 2000) with aflatoxin contamination. The positive correlation was also significant between A. flavus infection and aflatoxin, both for peanut obtained from farmer's level. 
Kernel moisture content most of peanut kernels sampled in wholesale and retail outlets was lower than $10 \%$ at most of the sampling times and therefore the incidence of aflatoxin contamination was also low or under the safe level of contamination. Despite a substantial proportion of damaged kernels both caused by mechanical and biological damage in seed lots obtained at each sampling time, these two elements did not govern the level of aflatoxin contamination. Time of sampling throughout the year did not affect the level of aflatoxin contamination. Under controlled condition generated from air-tight container and controlled condition, the influence of A. flavus infection and seed moisture content on aflatoxin production was significant.

\section{Conflict of interest}

Authors would hereby like to declare that there is no conflict of interests that could possibly arise.

\section{Acknowledgment}

The research was funded by Australian Center for International Agricultural Research through project \# PHT 97/017. Thanks are due to Dr. Rachaputi Nageswara Rao for improving the research proposal. We also thank to Miss Lina Kusumawati and Mr. Langgeng Sutrisno, for their kindly help in the laboratory and field activities.

\section{References}

Cole RJ, Sanders TH, Hill RA, Blakenship PD (1985) Mean geocarphosphere temperatures that induce preharvest aflatoxin contamination of peanuts under drought stress. Mycopathologia 9: 41-46

Crop Link (2000) Aflatoxin in Peanuts. Tips to Reduce the Risk. Queensland Department of Primary Industries. Farming Systems Institute. 12 pp

Dharmaputra OS (2002) Review on aflatoxin in Indonesian food and feedstuffs and their products. Biotropia 19: 26-46

Dharmaputra OS, Putri ASR, Retnowati I, Ambarwati S (2003) Aspergillus flavus and aflatoxin in peanuts at various stages of the delivery chains in Pati regency, Central Java Province. Research Report. SEAMEO BIOTROP. 24 pp (in Indonesian)

Dharmaputra OS, Retnowati I, Ambarwati S (2007) Aspergillus flavus and aflatoxin contamination in peanuts at various stages of the delivery chains in Wonogiri regency, Central Java Province. Biotropia 14 (2): 9-21.

Ginting E (2006) Quality and aflatoxin contamination in peanut seeds cultivar Kancil and Mahesa under several packaging materials. Jurnal Agrikultura 17(3):165-172 (in Indonesian).
Lee AN, Kennedy IR (2002) Practical 1. University of Sydney quick aflatoxin $\mathrm{B}_{1}$ ELISA Kit. Paper presented at ELISA Workshop Analysis of Aflatoxin $\mathrm{B}_{1}$ in Peanuts, held in Bogor on 12-13 February 2002. Organized by University of Sydney, ACIAR and SEAMEO Biotrop Bogor. 8 pp.

Lubulwa ASG, Davis JS (1994) Estimating the social costs of the impacts of fungi and aflatoxin in maize and peanuts. P. 1017-1042. In E. Highley et al (Eds). Stored Products Protection. Proc. The $6^{\text {th }}$ Inter. Working Conf. On StoredProduct Protection 1994 in Canberra, Australia.

Mehan VK, McDonald D, Lalitha B (1983) Effect of season, location and field drying treatment on in vitro seed colonization of groundnut genotypes by Aspergillus flavus. Oleagineux 38: 553-559

Ndung'u JW, Makokha AO, Onyango CA, Mutegi CK, Wagacha JM, Christie ME, Wanjoya AK (2013) Prevalence and potential for aflatoxin contamination in groundnuts and peanut butter from farmers and traders in Nairobi and Nyanza provinces of Kenya. Journal of Applied Biosciences 65: 4922 4934

Paramawati R, Widodo P, Budiharti U, Handaka (2006) The role of postharvest machineries and packaging in minimizing aflatoxin contamination in peanut. Indonesian Journal Agricultural Science 7: 16-20

Pitt JI, Hocking AD (1997). Fungi and Food Spoilage. Blackie Academic \& Profisional. London.

Pollet A, Declert C, Wiegandt W, Harkema J, van de Lisdonk E (1992) Three years' studies on relationships between traditional groundnut storage and aflatoxin problems in Coted'Ivoire. Main results. Oleagineux 47: 71-85

Rahmianna AA, Taufiq A, Yusnawan E (2004) Evaluation of ICRISAT groundnut genotypes for end-of-season drought tolerance and aflatoxin contamination in Indonesia. International Arachis Newsletter No 24: 14-17.

Rahmianna AA, Ginting E, Yusnawan E (2007a) Aflatoxin contamination on peanut at various stages of the delivery chain in Banjarnegara, Central Java. Jurnal Penelitian Pertanian Tanaman Pangan 26(2): 137-144 (In Indonesian).

Rahmianna AA, Taufiq A, Yusnawan E (2007b) Effect of harvest timing and post harvest storage conditions on aflatoxin contamination in groundnuts harvested from the Wonogiri regency in Indonesia. International Arachis Newsletter No 27: $43-45$.

Van Eden CF, van Rensburg JBJ, de $\mathrm{K}$ van der Linde TC (1994) The role of insect damage in the colonization of groundnut (Arachis hypogaea L.) pods by fungus. Afr. Tydskr. Plant Grond, 11: 159-162. 
Monitoring of Aflatoxin contamination at market food chain in east java.

Wotton HR, Strange RN (1985) Circumstantial evidence for phytoalexin involvement in the resistance of peanut to Aspergillus flavus. Journal General Microbiology 131: 487494.

Yameogo RT, Kassamba B (1999) Aspergillus flavus and aflatoxin on tropical seed used for snacks: Arachis hypogaea,
Balanites aegyptiaca and Sclerocarya birrea. Tropical Science 39: 46-49.

Yameogo RT, Kassamba B (1999) Aspergillus flavus and aflatoxin on tropical seed used for snacks: Arachis hypogaea, Balanites aegyptiaca and Sclerocarya birrea. Tropical Science 39: 46-49. 